\title{
Austrian Sustainable Building Policy Lessons for Turkey
}

\author{
Hatice Kalfaoğlu Hatipoğlu
}

\begin{abstract}
This paper explores the progress of sustainable building in Austria and its applicability for Turkey. First it explains the need for sustainability and the transition phase to sustainable building practices in Austria from the 1970s, exploring how these accelerated environmental performance. The paper describes Austria's policy, actors and initiatives with important milestones and its success as a benchmark country in terms of approaches to sustainable building. Secondly it discusses the state of art in Turkey and the translation of a sustainable Austrian building development model for Turkey. At the end, the paper demonstrates lessons from Austria's sustainable building policy and describes guidelines to further develop the sustainable building sector in Turkey.
\end{abstract}

Index Terms-Sustainable building, Austria, sustainable development, energy efficient building.

\section{INTRODUCTION}

The exhaustion of energy resources and heavy environmental impacts like ozone layer depletion, global warming and climate change have raised the concerns about energy efficiency. Building energy consumption, both residential and commercial, has steadily increased reaching figures between $20 \%$ and $40 \%$ in developed countries and has exceeded industrial and transportation sectors. Growth in population and increasing demand for buildings ensure this upward trend for energy demand will continue. For this reason, energy efficiency in buildings is today a prime objective for energy policy at regional, national and international level [1]. In organizations for economic development and co-operation (OECD) countries, the building sector reduces the carbon dioxide use to half through the work of policymakers, urban planners, designers and engineers [2].

After global energy crises, such as the 1973 and1979 oil shortage and the drastic increase in oil prices, European countries started to consider energy efficiency and effective use of energy resources. Because buildings use at least $40 \%$ of the world's energy and are the reason for at least $50 \%$ of $\mathrm{CO}_{2}$ emissionsthe1990s were a time of awareness for environment, ecology and the limits of energy sources for the EU and some other leading countries. "The Brundtland report [3]" in 1987 for the first time mentioned "sustainability" and described it with a three- column model of ecological, economic and social quality. Sustainable building started to lead by describing an architecture that uses energy systems thoughtfully to make buildings more conducive to human use and comfort, without generating pollutants or borrowing the

Manuscript received May 20, 2015; revised July 20, 2015.

Hatice Kalfaoğlu Hatipoğlu is with the Faculty for Architecture and Planning, Vienna University of Technology, Vienna, Austria (e-mail: haticekalfaoglu@hotmail.com). earth's resources for the future generations [4].With its agenda 21, the Rio de Janeiro Earth Summit in 1992 led the direction from low-energy to sustainable building. Agenda 21 has been an action agenda for the UN and its motto was "think global, act local"

At first, considerations were more about the ecological and economical quality of sustainability and later the importance of social, physical, biological and aesthetical quality. The European Community has always paid attention to sustainable building and its policymaking procedures and the building impacts on physical, social, and aesthetic quality in Europe $[5]$.

Austria has been a benchmark country in Europe, and by following the EU Standards, with measures and considerations for livability, energy efficiency and future viability, it has managed a sustainable building approach for over 20 years. Since the 1960s the Austrian building stock has about doubled; $25 \%$ of the material flow of minerals, $50 \%$ of waste arising, and almost $40 \%$ of the final use of energy are attributable to the building sector. Besides construction and renovation activities, space heating and cooling, hot water, lighting and home appliances also contribute to energy consumption in the building sector. Because of these demands, Austria has been aware of need for increased energy efficiency and a reduction of $\mathrm{CO}_{2}$ emissions and since the 1960s has been controlling environmental impacts of buildings and reduce use of energy. The policy not only addresses energy efficiency, but also quality of life. Social quality, livability, and participation have been all part of this strategy. According to Mercer's 2015 Quality of Living Survey, Vienna has been chosen for the sixth time as the most livable city in the world [6]. So sustainability has been a possibility to contribute to a better and livable future.

The aim of this article is to review the evolution of sustainable building processes in Austria, show how Austrian policy framework with regulations and initiations has been successful in developing and implementing sustainable building and describe lessons that Turkey should learn. This review demonstrates the progress of policy, how emerging energy efficient and sustainable housing start with low-tech solutions accelerate sustainable building and how important initiatives can support and encourage sustainable development in the building sector

In what follows, the applicability of an Austrian development model to Turkey is discussed. In Turkey sustainable building has still not received proper attention by the construction sector, government or society. Sustainability is motivated mostly by economic benefits, so environmental benefits have been seen as additional cost. It has no targets to reduce $\mathrm{CO}_{2}$ emissions, to encourage energy efficient buildings and has no subsidy to increase the number of these buildings. Architects, engineers and government have to motivate 
themselves about sustainability by considering its social, economic and ecological quality. There aren't also good examples of sustainable and energy efficient buildings to achieve level of expertise which is necessary to accomplish efficient buildings. Green concept has been a marketing tool and unfortunately the main motivation reason is economic benefits. In conclusion, the Turkish construction policy is crisis oriented. It attempts to create regulations, but these regulations are still "under construction" and there is a lack of standards for thermal regulations, good demonstration projects, implementation and initiatives. Government policy has to support sustainable building by taking measures, having targets, motivating stakeholders, encouraging initiatives and energy efficiency for a livable future and Austria can be a good example with its sustainable building policy with its initiatives, innovative solutions, measures and considerations.

\section{TRANSITION TO SUSTAINABLE BUILDING IN AUSTRIA}

\section{A. Seeds and Experimentation to Prepare Sustainability}

The1960s were the seed for ecological architecture. The book "Silent Spring" by Rachel Carson accelerated environmental worries and movements in the world. Architect Frank Lloyd Wright developed the concept of organic architecture with environmental inspirations which later led to ecological architecture.

OPEC (Organization of Petroleum Exporting Countries) oil embargo has awaked western countries and the 1970s were the years for "radical change for all Europe countries which increases considerations about energy and environmental aspects about buildings. In 1972 United Nations Conference on Human Environment in Stockholm was the first international recognition of environmental issues. High costs, threatening climate change and global warming accelerated attempts and the OECD (Organization for Economic Co-operation and Development) founded the IEA (International Energy Agency) which leads achieving the aim of Energy conservation. Austria was one of the main actors following and implementing these developments and Austrian policy and architects tried to develop concepts for energy efficiency, which also included the building sector.

In the 1960s in Vorarlberg, a small state in Austria, important steps toward sustainability were taken by local architects who tried to apply concepts of cost efficiency, technology and functionality. (see II-B Sustainable Model of Vorarlberg)

Hertha Finberg who was that time Austrian Minister of Science, Research and Economy observed that "the sun energy will rapidly gain more importance (significance) because of its inexhaustibility and the development of its use is expected to be very fast." [7]. Frey, an architect at the Environmental Research Institute Graz, has conducted research on alternative energy resources, solar architecture, sun collectors, and innovative systems. His Design House Fischer am Groundless (see Fig. 1) is the first prototype of a sun house in Austria (1972-1978). House Zankel is another solar house energy concept that he designed in collaboration with physicist Karl Zankel.

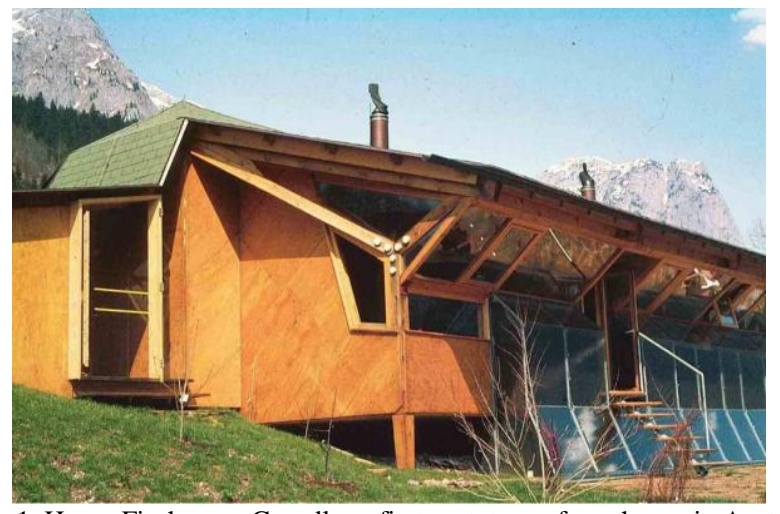

Fig. 1. House Fischer am Grundlsee, first prototype of sun-house in Austria, [8].

\section{B. The Sustainable Model of Vorarlberg}

Sustainable architecture focuses not only on ecological and economic factors, but also social and cultural. Vorarlberg is a good example [9]. Vorarlberg is a small Austrian state that is economically strong and is the most sustainable region in Austria. Sustainability was developed not for demonstration purposes, but to meet the needs of inhabitants.

This sustainability movement was started in the 1960s by local architects who tried to bring together cost efficiency, technology and functionality. The concepts are based on efficient structure, maximum usage of resources, usability and requirements of habitants. Their goal was to implement traditional principles and methods in contemporary architecture and to combine regional materials with new techniques. Such innovations present technical challenges, not only for new buildings, but for old buildings from the 1950s which require sensitive renovation regarding concepts and sustainability.

By combining hydropower, solar energy, geothermal power and biomass, the power which the region needs is produced. Building components are produced in the region and it is possible to reach the smallest villages with public transport so quality and density of public transport is similar to big cities. One third of all communities take part in the program for energy efficient communities.

In the passive house era, Energy Institute Vorarlberg, which was founded as an independent non-profit organization in 1985, was responsible for transferring information and concepts from Germany and focused on efficient use of energy and ecological buildings.

The first passive-house school in Austria was designed by Dietrich and Untertrifaller in Klaus, Vorarlberg. Many people from around the world come to visit the school and to see the Vorarlberg success. Helmut Kuess designed social housing projects that require less than $15 \mathrm{kWh} / \mathrm{m} 2$ a heating. The community center in Ludesch is another significant project by Hermann Kaufmann which uses only half of the energy demand of comparable buildings by sophisticated energy technology. In Vorarlberg there is a sustainable development with a balance of high-tech and low-tech, tradition and innovation.

Architecture has played a great role for this transformation of the region towards sustainability. There has been not competitiveness in different fields but integrative work and communication. 


\section{Start of Passive House Era in Austria}

The passive house roof was developed in the Vorarlberg project. After the EU-project "CEPHEUS 14];" stimulated some demonstration projects, the "Building of Tomorrow-Haus der Zukunft" (see IV-A) was established. These initiatives accelerated the emergence of passive houses.

Austria's first passive house was built in 1996 in Vorarlberg. The year after, two housing complex were designed regarding passive house technology. The first terraced housing complex by Atelier Unterrainer in Batschuns-Vorarlberg (Fig. 2) and housing complex with 13 apartments by architect Hermann Kaufmann in Vorarlberg. Both projects have won the "House of Tomorrow" award.

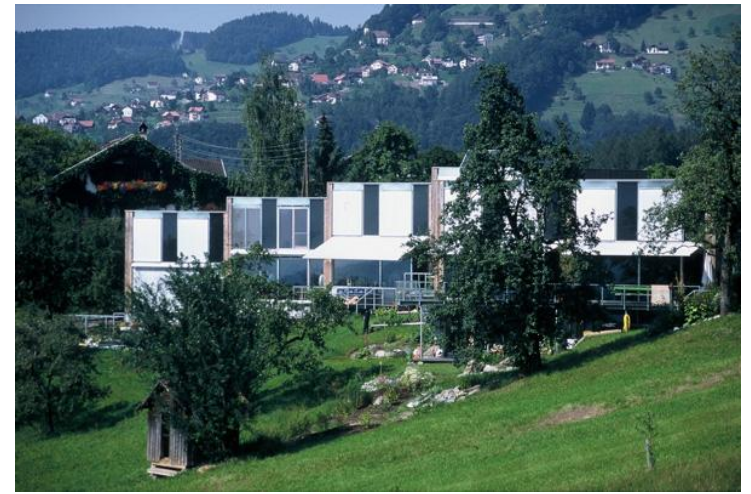

Fig. 2. The first terraced passivehousing complex, Batschuns [11].

\section{INTENSIVE REGULATIONS AND MEASURES AFTER 2000S}

\section{A. Strategy for Sustainable Development}

In April 2002 the Austrian government adopted the Austrian Strategy for Sustainable Development (NSTRAT: Österreichische Strategiefür Nachhaltige Entwicklung). The fields of action are separated into 4 categories; Quality of life in Austria, Austria as a dynamic business location, Austria as a living space, and Austria's responsibility. In 2010 the Austrian federal states together with the Austrian government prepared a collective Austrian strategy for sustainable development (ÖSTRAT), which can be seen as a guideline towards a sustainable Austria and the first progress report was published in 2011. (This was built on the aims and principles of NSTRAT in 2002)

\section{B. Energy Strategy and Energy Performance Certificate of EU and Austria}

"The Building Energy Performance Directive (EPBD) [12]" was approved in 2002 and brought into force in 2003. The aim of the directive is to improve energy performance of buildings within the EU through cost-effective measures.

The adaptation of the EU Energy Performance Certification into national law resulted in a formal proposal to harmonize building regulations in Austria which are the responsibility of the Österreichisches Institutfür Bautechnik, OIB (Austrian Institute of Construction Engineering') in Directive 6: Energy saving and thermal insulation [13].

During the period 2005 Energy and Climate legislations (the base year of the EU Energy and Climate targets) until 2009 a lot of measures were taken by the Austrian policy which have significant positive effects to reach energy policy objectives.

In 2008 the EU's Climate and Energy policy 20/20/20 began targeting [14];

- A reduction in greenhouse gas emissions of at least $20 \%$ below 1990 levels

- $20 \%$ of energy consumption to come from renewable resources

- An increase in energy efficiency by $20 \%$ by 2020 .

In April 2009,180 experts from the federal administration, federal provinces, scientists, business, and social partners discussed and developed measures for the energy efficiency strategy. The process was divided into 9 different fields and included 370 recommendations. Austria defined its 2020 Targets:

- $20 \%$ more energy efficiency

- $34 \%$ share of renewable energy

- $16 \%$ reduction of GHG emissions in non-ETS sectors (it has been a reduction by $39 \%$ compared with 2005)

Fig. 3 shows share of final energy consumption in building sector in 2007 and the target share of renewable energy for the year 2020 .

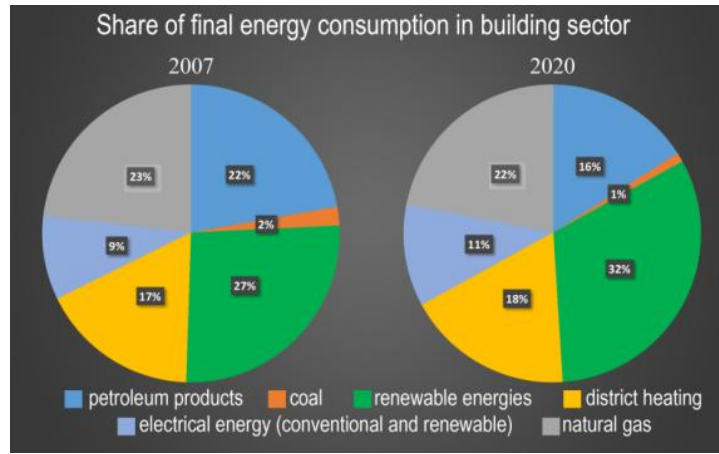

Fig. 3. Share of final energy consumption in building sector 2007 and 2020 [15].

Fig. 4 shows the total greenhouse gas emissions in building sector in 2005 and target value of greenhouse gas emissions for the year 2020 .

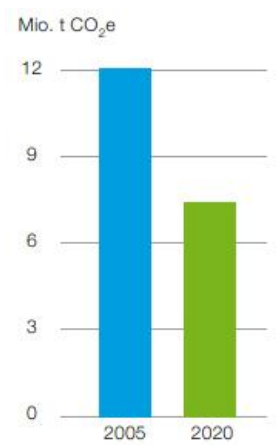

Fig. 4. Total greenhouse gas emissions in building sector 2005 and 2020 [16].

The objective of the Austrian Energy strategy is to develop a sustainable energy system that makes energy services available for private consumption as well as for businesses in the future whilst implementing EU rules. In order that the demand for services be met in a way that is compatible with EU objectives, a target for final energy consumption in 2020 has been fixed. The target for final energy consumption in Austria in 2020 is $1,100 \mathrm{PJ}$.

As a result energy efficiency was the key point of Austrian 
energy politic and the important areas to address are;

- Buildings: decrease heating and cooling demand

- Energy use in households- with an emphasis on power consumption und heat utilization

- Efficient mobility

Energy efficiency improvement by household sector by $23 \%$ in 2010 compared to 1990 . Fig. 5 shows this indices according to the years.

After these targets, Austrian Minister of Economy Reinhold Mitterlehner and Minister of Environment Nikolaus Berlakovich presented second stimulus package for thermal improvements. According to the package for private buildings for housing and business 50 million Eurosubsidy was provided for insulation of their shells and replacement of heating boilers and windows.

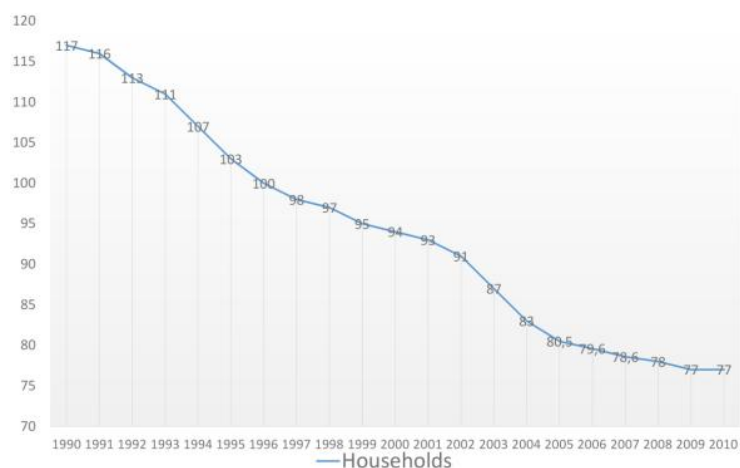

Fig. 5. Energy efficiency indices by household sector from 1990 to 2010 [17].

Important measures for building sector:

- With an agreement between the government and the provinces important steps have been taken to reduce Energy use and greenhouse gas emissions.

- The Act on the Presentation of an Energy Performance Certificate

- Amendments for building and air quality regulations of federal states.

- Funding for switch to renewable energy sources in heating rooms. by government and states.

- Sanierungss check (renovation check) 2009: Incentives and funding of the Federal Government for private single-family or two family houses

\section{INITIATIVES}

\section{A. Haus der Zukunft Initiative}

The "Haus der Zukunft - Building of Tomorrow" initiative is a research and technology program which was developed in 1999 as a basis for innovative, sustainable concepts for buildings by the Austrian Ministry of Transport, Innovation and Technology. Some of the most important developments in the field of solar and energy-efficient construction include the solar low-energy approach and the Passive House. In this program, new designs and concepts have been developed and implemented such as the low-energy solar building approach, the concept of passive buildings, and ways of using environmentally friendly and renewable materials in construction. The following criteria are described for "Building of Tomorrow";
- Reducing energy and material use significantly

- Increasing the use of renewable energy sources, especially solar energy.

- Using primarily ecological materials efficiently

- Supporting social aspects in buildings and improving quality of life.

An extended second phase of the program was "Building of Tomorrow Plus" which encouraged buildings to generate more energy than they need which means producing more energy during their life of operation. The following aims are currently prioritized:

- Creating the technological basis for the building of tomorrow, especially the plus-energy house.

- Extending the program to office and factory buildings

- Encouraging industrial use of innovative technologies

- Initiating demonstration projects to put new technologies and approaches on the map.

- Supporting the interlinking of the key Austrian providers by some strategies, networking and education to integrate existing knowledge into suitable schemes.

Since the beginning of 2010, six consecutive calls have been carried out; of 700 proposals, 300 have been approved. The Austrian Ministry of Transport, Innovation and Technology has provided more than 35 million euros in support.

"Building of Tomorrow" has led to eco-efficient construction and the sustainable use of resources in Austria [18]:

- Scientific expertise in this field has been increased

- Passive house density in Austria is the highest world-wide

- Austrian companies are leading technological construction in the field of sustainable building in the world

- The system adaption of subsidies to construction of buildings has been supported

- The results of the program has been incorporated by "klima: aktivhaus" program of the Ministry of the Environment.

Fig. 6 shows passive house development in Austria from 1996 to 2015, which "Building of Tomorrow" initiative has been a leading actor. In 2015 there is more than 36000 passive housing units in Austria.

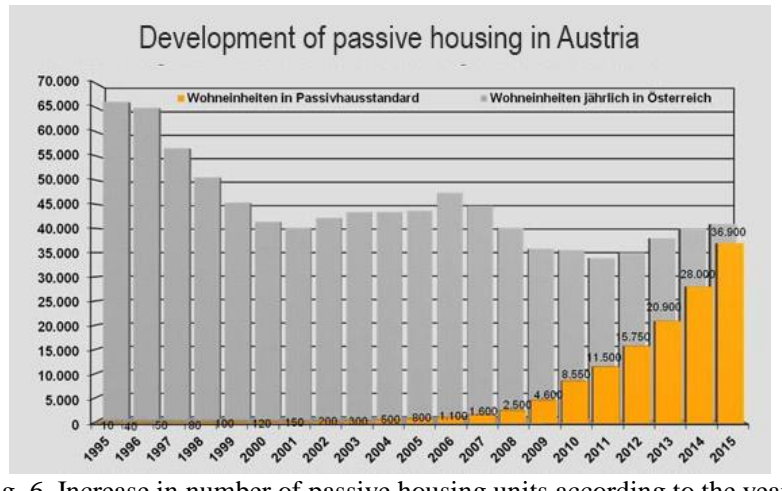

Fig. 6. Increase in number of passive housing units according to the years [19].

The "Haus der Zukunft: Building of Tomorrow" initiative aims to achieve the highest level of energy efficiency in building construction and reduce greenhouse gas emissions to zero as a long term vision. This vision transforms buildings from consumers to producers of energy during their life cycle. 


\section{B. Klima: Aktiv Initiative}

"Klima: aktiv" is an initiative to protect climate which was launched in 2004 by the Austrian Ministry of Agriculture, Forestry, Environment and Water Management and is part of the Austrian climate strategy. The purpose of klima:aktiv is to support development of climate friendly technologies and services.

The klima: aktiv has achieved a great deal since 2004; transparent standards, advice and support for building and renovation, for heating systems and heating plants, on how to save energy, and has won the award the trophy for best practice in the 2011 European Public Sector Award (EPSA). Through klima: aktiv, many companies have optimized their production processes, and by integrating other measures, the $\mathrm{CO}_{2}$ emission have been reduced by 1.6 million tons a year [20].

The klimaaktiv initiative is classified into four main categories: building \& renovation, energy efficiency, renewable energy and mobility. Along these categories thread buildings and transport which are the main emission causes and efficiency and renewable energy which are the main solutions.

In building renovations, klima: aktiv requires more than efficient use of energy. It focuses on ecological quality, comfort, good planning, high-quality building materials, and energy efficient building methods to reduce the energy requirements of a building and also enhance the quality of life. The klima: aktiv building standard has been established as a benchmark for ecological buildings which has not only been assessed in klima: aktiv buildings, but also in general in terms of the quality of the planning and execution, the building material and construction quality, comfort and air quality. These standards are categorized according to building type: residential, office buildings, hotels, schools and also for new buildings and for renovations. Around 24,0000 m2 in the residential building sector and over $180,000 \mathrm{~m} 2$ in the service building sector have already been built in compliance with the klima: aktiv standard [21].Funding policies in the building sector have been developed as well as educational courses to qualify specialists for the optimization of energy efficiency and renewable energy technologies. The klimaaktiv standard is also a quality level for the Austrian State Awards for Architecture and Sustainability.

\section{C. ÖGNB and Total Quality Building (TQB)}

"The Austrian Society for Sustainable
Building"(Österreichische Gesellschaftfürnachhaltiges Bauen, ÖGNB) was initiated in 2009.The founders of this initiative are the Austrian Institute for Building Biology and Ecology (Österreichisches Institutfür Baubiologie und Bauökologie, IBO) and the Austrian Institute for Ecology (Österreichisches Ökologie-Institut, ÖÖI). In the same year board members from the Austrian Energy Agency, Energieinstitut Vorarlberg, the Austrian Society for Environment and Technology (Österreichische Gesellschaftfür Umwelt und Technik, ÖGUT) officially began to work together.

The $O ̈ G N B$ has produced an assessment system TQB-Tool, like many others assessment tools such as 'LEED',
'BREEAM', which includes a criteria catalogue to define requirements for sustainable buildings and provides assessment and an energy performance certificate. This assessment system has indicators and an assessment scale which scores good and poor performance by scores. During assessment the data are collected and according to these criteria checked. These criteria are [22]:

- Location and amenities

- Economical and technical quality

- Energy and water

- Health and comfort

- Resource efficiency

\section{D. $\ddot{O} G N I$}

The Austrian Sustainable Building Council (Österreichische Gesellschaftfür Nachhaltige Immobilienwirtschaft, ÖGNI) was founded in 2009 to find solutions for building, using and managing sustainable real estate and to promote of ethical business. The $\ddot{O} G N I$ is linked to the German Sustainable Building Council (Deutsche Gesellschaftfür Nachhaltiges Bauen, DGNB). This initiative aims to adapt the DGNB assessment system to Austria.

German Sustainable Building Council Certification $(D G N B)$ includes all significant fields of sustainable construction and has three awards: bronze, silver, and gold.

\section{E. Smart City Wien}

The big "Smart City Wien" initiative was launched by Mayor Michael Häupl in 2011 to use innovative concepts to enhance to the quality of life in Vienna. A smart city is a city that faces challenges in the wake of decreasing resource consumption combined with rising demands. However a smart city will also strive for a high degree of social inclusion. It needs to optimize resources while ensuring high quality of living combined with innovation in all fields [23].

The first aim of this strategy is efficient use of resources andreduce $\mathrm{CO}_{2}$ emissions which means resource conservation. The second is a better quality of life for all people. The first aim provides the basis for the second.

At the end of 2011, the Vienna Climate Protection program (Klip: Klimaschutzprogramm), reduced $\mathrm{CO}_{2}$ consumption by 37 million tons. In international comparison this is a very good performance. Between the years 1990-2010 $\mathrm{CO}_{2}$ emissions in Vienna were reduced by $21 \%$ per capita and nevertheless by $10 \%$ [24].

\section{Energy objectives:}

- Increase energy efficiency and decrease final energy consumption per capita in Vienna by $40 \%$ by 2050(compared to 2005)

- Primary energy input per capita should be decreased to 2000 watt from 3000 watt.

- Over $20 \%$ of Vienna's gross energy consumption will be gained from renewable resources in 2030, and over $50 \%$ in 2050.

\section{Building objectives:}

- Zero-energy building standards for all new structures, renovations and refurbishments to optimize costs from 2018-2020 and to protect climate better by developing heat supply systems further

- To reduce energy consumption of existing buildings for heating/cooling/water by one percent per capita and year 
by comprehensive rehabilitation activities.

\section{CONCLUSION: LEARNING FROM VIENNA}

The paper has described the process through which sustainable policies, initiatives, and practices have been implemented in Austria's building sector.

In Turkey sustainability is a current issue in the building sector but is motivated economically and efforts are short-term in nature. Government policy has focused on earthquake measures and urban transformation for poor regions. Ministries have a plan to create sustainable development but the scheme is still under development and has not been implemented. There is no collaboration among different stakeholders, so a sustainable national policy has not yet been established. Although there is an energy performance certificate, an international assessment and certification system which is necessary to support sustainable development, is still missing.

Although Austria and Turkey differ in terms of climate, economics and culture, the environmental problems of the building sector are similar so a translation of policies and techniques is possible, helpful and necessary. In an analysis of "Agenda 21 for Sustainable Construction in Developing Countries [25]" it has been noted that the problems of developing countries are more complex than others. More specifically, first there is a very fast construction boom which places enormous pressure on the environment, and second there is lack of infrastructure, especially in slums and illegal settlements but also in new building areas, which pollute soils and water bodies. Urban transformations in these urban areas are another reason for building construction. There are not enough considerations and measures to reduce $\mathrm{CO}_{2}$ emissions and greenhouse gases. If we compare total greenhouse gas emissions of Turkey and Austria between the years 1990 and 2012, we can reach the fact that Greenhouse gas emissions in Austria decreases almost to the value in 1990 with its sustainable policy and Greenhouse gas emissions in Turkey in 2012 is much more than twice in 1990 (Fig. 7). That shows us, construction activities as a process and product in Turkey need to be directed toward sustainable development, some measures should be considered and taken seriously. These measures and considerations are necessary to make livable buildings and urban spaces with social, economic, ecological, aesthetical quality for us and generations to come.

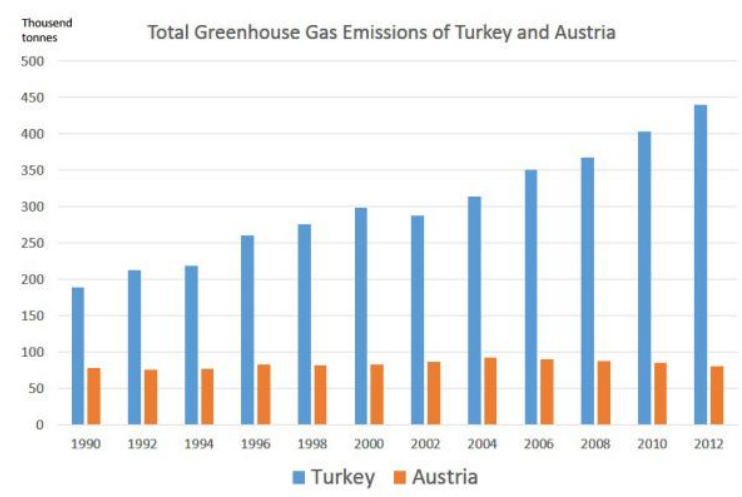

Fig. 7. Total Greenhouse gas emissions of Turkey and Austria between the years 1990 and 2012 [26].
Austria as a benchmark country that has experience implementing sustainable development in the building sector has relevant guidelines for sustainable building and urban design for Turkey. Government must address environmental problems with regulations, initiatives and subsidies to develop sustainability. This agenda must be implemented by actors of construction. Partnership and dialog between different stakeholders can raise awareness of environmental problems and the need for sustainable development because a sense of partnership and commitment between the government and construction industry is required to put such a model.

As a result, we can sum up some recommendations that can be learnt from Austrian Sustainable Building Policy to develop sustainable buildings for Turkey:

- Policy, regulations, initiatives, packages to promote sustainable building and urban development.

- Holistic thinking about sustainability, with social, economic, ecological quality, which provides a quality of life and livable places.

- Demonstration projects which show the benefits of sustainable buildings.

- Implementation of passive house and zero energy house technics in buildings.

- Subsidies to encourage energy efficient building

- Setting 2020-2050 targets for energy efficiency and sustainability.

- Create a national assessment and certification system which encourages sustainable building

- Need for collaboration between different stakeholders.

\section{REFERENCES}

[1] L. P. Lombard, J. Ortiz, and C. Pout, "A review on buildings energy consumption information," Universidad de Sevilla, Sustainable Energy Centre, BRE, Watford, United Kingdom, 2007.

[2] B. Edwards, Green Buildings Pay, London: E\&FN Spon, 1998.

[3] G. H. Brutland, Our Common Future, Oxford University Press, Oxford, 1987.

[4] A. Ray-Jones, Sustainable Architecture in Japan: The green Buildings of Nikken Sekkei, London, Great Britain: Wiley-Academy, 2000.

[5] B. Edwards, "Towards sustainable architecture, European directives \& building design," Oxford: Butterworth Architecture Legal Series, 1996.

[6] Mercer quality of living Survey (2015). [Online]. Available: http://www.wien.info/en/lifestyle-scene/most-livable-city

[7] G. Spielmann, “The Austrian sunhouse," Vienna, 1921.

[8] K. Frey. (1972-1978). House fischer at Grundlsee. First Prototype of a Sunhouse in Austria. [Online]. Available: http://www.gat.st/en/news/konrad-freys-well-tempered-environment

[9] G.-M. Dominique, "Ecological architecture in Vorarlberg, a social, economic and cultural model," Heidelberg, Berlin, 2011.

[10] J. Schnieders and A. Hermelink, "CEPHEUS results: Measurements and occupants'satisfaction provide evidence for passive houses being an option for sustainable building," Energy Policy, vol. 34, pp. 151-171, 2006.

[11] W. Unterrainer. (1997). The first terraced passivehousing complex in Austria. Batschuns. [Online]. Available: http://www.architekt-unterrainer.com/projects

[12] Directive 2002/91/EC of the European Parliament and of the Council. (2003). On the energy performance of buildings. Official Journal of the European Communities. [Online]. pp. 65-71. Available: http://eur-lex.europa.eu/LexUriServ/LexUriServ.do?uri=OJ:L:2003:0 01:0065:0071:EN:PDF

[13] Austrian Institute of Building Technik. Regulations. [Online]. Available: http://www.oib.or.at/

[14] The Climate Action and Renewable Energy Packageof EU. (2008) Europe's climate change opportunity. [Online]. Available: http://ec.europa.eu/environment/climat/climate_action.htm 
[15] Federal Ministry of Science, Research and Economy, Austria, Energy Strategy Austria Report, Vienna, 2010.

[16] Federal Ministry of Science, Research and Economy, Austria, Energy Strategy Austria Report, Vienna.

[17] Austria Energy Agency, "Energy efficiency policies and measures in Austria," Vienna, 2010.

[18] Federal Ministry of Science, Research and Econom, "10 years building of Tomorrow," Vienna, 2009.

[19] IGPassivhaus. (2015). http://www.innovativegebaeude.at/

[Online]. Available:

[20] Federal Ministry of Agriculture, Forestry, Environment and Water Management, Austria, Annual Report of Klima: Aktiv, Vienna, 2011.

[21] Federal Ministry of Agriculture, Forestry, Environment and Water Management, Austria, Annual Report of Klima: Aktiv,Vienna, 2011, p. 9.

[22] ÖGNB (Austrian Sustainable Building Council). (2010). Demo project. [Online]. Available: https://www.oegnb.net/tqbtest.htm

[23] Smart City Wien, "Smart city wien framework strategy," Vienna City Administration, Vienna, 2014.

[24] AEA (Austrian Energy Agency), "Evaluation of implementation of climate protection programme of city Vienna," Vienna, 2011.

[25] CIB \& UNEP-IETC, "Agenda 21 for sustainable construction in developing countries: A discussion document," CSIR Building and Construction Technology, Pretoria, 2002.
[26] EEA. (2015). Greenhouse Gas Emissions. [Online]. Available: http://appsso.eurostat.ec.europa.eu/nui/show.do?dataset=env_air_gge \&lang=en

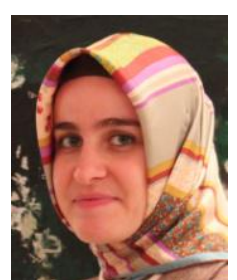

Hatice Kalfaoglu Hatipoglu was born in Konya, Turkey in 1984. She received the B.Eng., and MSc. (Dipl.Ing) degrees in architecture and planning from Vienna University of Technology, Vienna, Austria, in 2008. She has been doing her Phd in architecture and planning in Vienna University of Technology, Vienna, Austria.

She worked as an intern in Architecture Offices Coop Himmelblau in Vienna and Mimarlar in Turkey. She worked as an architect and a designer in BG4 Architects, Zauhenberger Architecture Office and Espace Design \& Visualisation Company. She is currently a research assistant at Architecture Department, Yildirim Beyazit University, Ankara, Turkey. She has published an article about Austrian architect clemenz holzmeister's works in vindobona magazin. Her current research interests are housing design quality and sustainability. 